
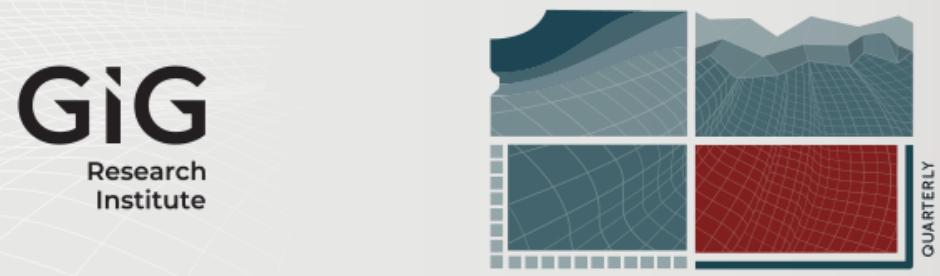

JOURNAL

OF

SUSTAINABLE

MINING

Volume $21 \mid$ Issue 1

Article 2

2022

\title{
The use of microalgal sourced biodiesel to help underground mines transition to battery electric vehicles
}

Author(s) ORCID Identifier:

Corey Laamanen (iD) 0000-0002-1321-0491

Sabrina M. Desjardins (iD) 0000-0003-3691-7323

Shannon H. McLean (D) 0000-0001-9900-640X

John A. Scott (iD) 0000-0002-2559-0188

Follow this and additional works at: https://jsm.gig.eu/journal-of-sustainable-mining

Part of the Explosives Engineering Commons, Oil, Gas, and Energy Commons, and the Sustainability

\section{Commons}

\section{Recommended Citation}

Laamanen, Corey A.; Moreau, Kyle; Desjardins, Sabrina M.; McLean, Shannon H.; and Scott, John A. (2022)

"The use of microalgal sourced biodiesel to help underground mines transition to battery electric vehicles," Journal of Sustainable Mining: Vol. 21 : Iss. 1 , Article 2.

Available at: https://doi.org/10.46873/2300-3960.1327

This Research Article is brought to you for free and open access by Journal of Sustainable Mining. It has been accepted for inclusion in Journal of Sustainable Mining by an authorized editor of Journal of Sustainable Mining. 


\title{
The use of microalgal sourced biodiesel to help underground mines transition to battery electric vehicles
}

\author{
Abstract \\ The use of fossil fuel sourced diesel underground has various associated health and environmental \\ hazards, and additional energy demand and costs associated with necessary ventilation. One way to \\ reduce these impacts is by utilizing a biodieselblend, which generates lower levels of harmful emissions \\ from underground equipment and can be produced regionally, reducing the impact of transportation. \\ Furthermore, this would help allow use of existing machinery during transition towards more widespread \\ electrification underground. Therefore, the concept of an integrated supply and use chain within the \\ mining industry is examined based on biodiesel from acidophilic photosynthetic microalgae cultivated \\ using $\mathrm{CO} 2$ in smelter off-gas. A life cycle assessment (LCA) was conducted to compare the \\ environmental impacts of production, transportation, and end-use of fossil fuel sourced diesel to \\ biodieselblended fuel across four underground metal ore mine sites (Canada, Poland, Zambia, and \\ Australia). The outcomes from assessing four key environmental impact potentials (global warming, \\ eutrophication, acidification and human toxicity) demonstrate the advantages of using biodiesel-blends. \\ The integration of biodiesel resulted in changes of $-22.5-+22.8 \%$ (global warming), $-6.1-+27.3 \%$ \\ (eutrophication), $-18.9-+26.3 \%$ (acidification), and $-21.0--3.6 \%$ (human toxicity). The results showed \\ reduction across all potentials for two mines and reduction in human toxicity potential for all sites.
}

\section{Keywords}

Environmental benefits, microalgae, biofuel, life cycle assessment, metals, underground mining

\section{Creative Commons License}

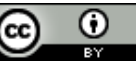

This work is licensed under a Creative Commons Attribution 4.0 License.

\section{Authors}

Corey A. Laamanen, Kyle Moreau, Sabrina M. Desjardins, Shannon H. McLean, and John A. Scott 


\title{
The use of microalgal sourced biodiesel to help underground mines transition to battery electric vehicles
}

\author{
Corey A. Laamanen, Kyle Moreau, Sabrina M. Desjardins, \\ Shannon H. McLean, John A. Scott*
}

Laurentian University, Bharti School of Engineering, Canada

\begin{abstract}
The widespread use of fossil fuel sourced diesel underground has various associated health and environmental hazards, and additional energy demand and costs associated with necessary ventilation. One way to reduce these impacts is by utilizing a biodiesel-blend, which generates lower levels of harmful emissions from underground equipment and can be produced regionally, reducing the impact of transportation. Furthermore, this would help allow use of existing machinery during transition towards more widespread electrification underground. Therefore, the concept of an integrated supply and use chain within the mining industry is examined based on biodiesel from acidophilic photosynthetic microalgae cultivated using $\mathrm{CO}_{2}$ in smelter off-gas. A life cycle assessment (LCA) was conducted to compare the environmental impacts of production, transportation, and end-use of fossil fuel sourced diesel to biodiesel-blended fuel across four underground metal ore mine sites (Canada, Poland, Zambia, and Australia). The outcomes from assessing four key environmental impact potentials (global warming, eutrophication, acidification and human toxicity) demonstrate the advantages of using biodiesel-blends. The integration of biodiesel resulted in changes from -22.5 to $+22.8 \%$ (global warming), from -18.9 to $+26.3 \%$ (acidification), from -6.1 to $+27.3 \%$ (eutrophication), and from -21.0 to $-3.6 \%$ (human toxicity). The results showed reduction across all potentials for two mines and reduction in human toxicity potential for all sites.
\end{abstract}

Keywords: environmental benefits, microalgae, biofuel, life cycle assessment, metals, underground mining

\section{Introduction}

$\mathrm{T}$ he environmental footprint of metal production is increasing as the demand for metals rise due to population and economic growth, whilst ore grades decline and become harder to access [1]. However, there is significant opportunity for improvement through improved energy efficiency and use of renewable resources, including biofuels [2]. One of the International Council on Mining and Metals' ten principles states "pursue continual improvement in environmental issues, such as water stewardship, energy use and climate change" [3]. To achieve continual improvement, the mining sector needs a balance between economic activity and environmental concerns, allowing for cost efficient metal production without significantly reducing the quality of the environment for future generations [1,4]. To achieve these improvements, the first step is to quantify the environmental impacts of mining and identify ways to reduce them without compromising production [5].

A move to greater use of battery-electric vehicles (BEVs) helps address these concerns and is a trend in mining [6,7], but most existing underground mines still rely heavily on, and have a large investment in, fossil fuel powered diesel vehicles. The use of these diesel powered vehicles attributes directly to the necessary high levels of extractive ventilation, which account for up to $50 \%$ of a mine's total electrical energy costs [8]. This ventilation is key to limiting operator exposure to carbon monoxide,

Received 26 April 2021; revised 26 August 2021; accepted 13 September 2021.

Available online 5 January 2022

* Corresponding author.

E-mail address: jascott@laurentian.ca (J.A. Scott). 
hydrocarbons, nitrogen oxides and particular matter emitted from diesel engines [9].

The use of BEVs results in higher productivities, improved preventative maintenance, lower underground emissions, and reduced scheduled and unplanned maintenance compared to their traditional diesel counterparts $[10,11]$. This leads to lower overall operational costs and the ability to offset any differences in initial capital costs [12]. While the move from lead acid to lithium ion batteries have made BEVs more economically and physically feasible, further development is required to provide lighter, safer, and longer lasting options [13]. There is a general need for new battery chemistries in order to deal with large scale implementation of BEVs [14]. Other related concerns with the utilization of current BEVs underground include developing proper disposal of depleted batteries [15], the capital costs of implementation [12], and fire hazards from damaged batteries reacting with moisture or thermal runaway as cell temperatures increase beyond $60^{\circ} \mathrm{C}$ [15].

As such, while the potential of BEVs remains enticing, development and implementation will take time, not least due to very significant investment in diesel-powered vehicles. As such, there is potential to implement the use of BEVs as replacements when equipment reaches the end of its useful life, the length of which is dependent on the type of vehicle. For example, load-haul-dump machines (LHDs) should have a useful life of $12,000 \mathrm{~h}$ after a rebuild at $7500 \mathrm{~h}$. With an average utilization of around $4000 \mathrm{~h}$ per year, LHDs need to be replaced every three years [16] (which is in line with the typical lifetime of the battery [12]). The useful lives of LHDs and other equipment should be improved with improving onboard diagnostics and improved maintenance practices [16]. There is, therefore, an opportunity for an interim solution for the mining industry to allow it to obtain maximum return on its existing investment in machines whilst transitioning to BEVs.

One approach is to improve overall environmental performance of existing diesel-powered infrastructure and reduce emissions underground, while still meeting performance and power requirements, is through increased use of biodiesel. A $75 \%$ biodiesel blend (B75) in underground mining operations resulted in a $22 \%$ reduction in respirable diesel particulate matter and a $28 \%$ reduction in nitrogen dioxide, when compared to low sulfur fossil fuel sourced diesel [17]. However, use of a B20 ( $20 \%$ biodiesel) blend underground was still found to reduce elemental and total carbon emissions by $20 \%$, decrease in carbon monoxide emissions slightly, and reduce aerosol concentrations by $13 \%$ [18]. It is also worth considering that biofuels can substantially contribute to regional energy security and socio-economic development [19].

While some results suggest that vehicles not optimized for biodiesel have shown a slight decrease $(9 \%)$ in energy per litre compared to petrochemical diesel. Volumetric consumption of biodiesel is increased directly with the lower energy content per litre, as the energy efficiency is typically the same or slightly increased [20]. Despite this increase, utilization of biodiesel has consistently shown a decrease in harmful emissions. Biodiesel generates little to no sulphur emissions [21], and considerable reductions in carbon monoxide and particulate matter [22]. Although, depending on the combustion conditions of the engine [23,24], both increased [25,26] and decreased [27] $\mathrm{NO}_{\mathrm{x}}$ emissions have been reported. Biodiesel has been also shown to decrease global warming potential and ozone layer depletion when compared to petrochemical diesel [28]. Khalife et al. [23] did a comprehensive review of additives to biodiesel blends on the performance of diesel engines. Their data made it clear that there is potential for utilization of biodiesel blends, whilst also highlighting that further work is required on engine performance. It is important to note, therefore, the need for adaptation and optimization of diesel engines, and the associated costs, for effective utilization in the mining industry.

Biodiesel comprises of fatty acid methyl esters (FAMEs) derived from biological feedstocks, which are typically organized by generations. First-generation biodiesel is derived from food crops (e.g., sugarcane or canola) and second-generation from non-food bio-feedstocks (e.g., agricultural wastes or forestry). However, both have issues, including competing with food crops for arable land and low aerial productivity.

Micro- and macro-algae provide the principal biofeedstock for third generation biodiesel. Photosynthetic microalgae have been the preferred feedstock as they can achieve up to $80 \%$ lipid content per dry weight of biomass in the extreme case [29], but more commonly in the $30-40 \%$ range [30]. They can be also grown year-round on non-arable land, use a variety of liquid media (e.g., freshwater, saltwater or wastewater) and importantly provide an opportunity to directly mitigate industrial $\mathrm{CO}_{2}$ emissions [31,32], including those from ore smelting [33]. Furthermore, compared to first and second generation biodiesels, microalgae have an over $85 \%$ increased biodiesel areal production rate [34,35].

This paper uses a life cycle assessment (LCA) approach to model the impact of using a microalgae sourced biodiesel blend in four underground metal ore mine sites (Canada, Australia, Zambia and 
Poland). The biodiesel was assumed to be produced from lipids extracted from acidophilic microalgae grown using ore smelter off-gas $\left(6 \% \mathrm{CO}_{2}\right)$ as their carbon source. The intention was to assess the benefits of an integrated supply and use chain by taking into account location, operation and climate differences on four commonly assessed environmental impact potentials (global warming, eutrophication, acidification and human toxicity). These potentials are well defined categories that provide a basis for comparison within industries such as mining [36,37].

The LCA model (Fig. 1) developed compared emissions from fuel production (diesel or biodiesel), fuel transportation to the mine site, and overall emissions from mining operations, including from fuel use.

\section{Materials and methods}

\subsection{Goal and scope}

The initial goal was to estimate the maximum achievable biodiesel blend at each of the four mine sites based on how much could be produced from mitigating smelter $\mathrm{CO}_{2}$ emissions (see Section 2.2). Once the highest biodiesel blend per site was determined, an LCA could be then conducted to describe and contrast the global warming, eutrophication, acidification, and human toxicity potentials of two scenarios. The first scenario was full petrochemical sourced diesel operation and the second using a biodiesel blend. To obtain this, production, transportation, and overall operations emissions for both scenarios were examined and compared.

Microalgae cultivated in captured $\mathrm{CO}_{2}$-rich off gas have shown favourable fixation rates in industries such as coal-fired power generation [38] and cement production [39]. Therefore, an important criterion for biomass cultivation was to utilize waste $\mathrm{CO}_{2}$ from associated ore smelting, which in many cases is carried out near the mine, thereby providing regional access to a $\mathrm{CO}_{2}$ source to enhance microalgal production. Based on stoichiometric calculations, a kilogram of microalgae (dry weight) with a $50 \%$ carbon content can bio-fixate approximately $1.8 \mathrm{~kg}$ of $\mathrm{CO}_{2}$. A nickel ore smelter $[33,40]$ which produces approximately 95,000 tonnes of matte and $760 \mathrm{Mm}^{3}$ of furnace off-gas annually, was used as a standard size and assumed to be located $10 \mathrm{~km}$ from each mine site to provide a basis for comparison. Each mine location was evaluated for microalgae growth under local climate conditions and utilizing smelter furnace off gas containing $6 \% \mathrm{CO}_{2}$ [33] as a source of carbon and, where needed, waste heat for maintaining bioreactor temperature.

\subsubsection{Mine site description}

Four regionally distinct underground copper mines were used to compare the impact of both mine size and climatic variations on microalgae growth (Table 1). The mine sites selected are spread out over four continents and provide the study with a variety of environmental conditions, mine operations, production rates, fuel requirements, and primary electricity generation methods.

To quantify the potential for biodiesel as a transitional option towards the implementation of BEVs, and to allow for the fuel requirement in Table 1, the vehicle fleet at each mine site was examined. The results are summarized in Table 2.

While to accurately quantify the impact of electricity usage, a breakdown of regional electricity generation and average greenhouse gas (GHG) emissions factor for each region investigated is provided in Table 3.

\subsubsection{System boundaries}

The base scenario involves petrochemical diesel production at the nearest refinery to the mine

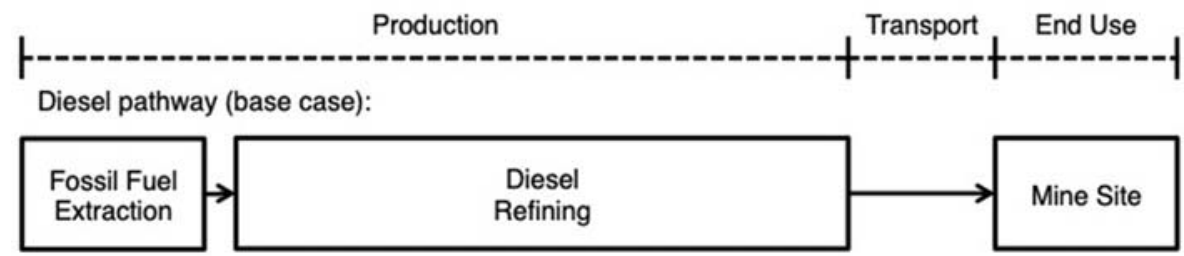

Biodiesel pathway:

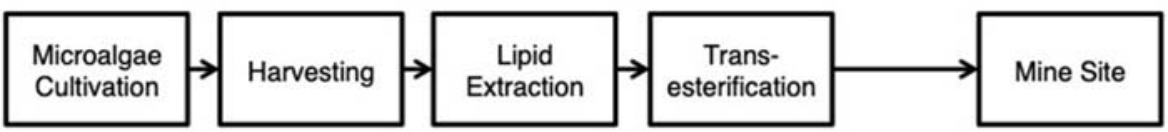

Fig. 1. Pathways considered by the LCA. 
Table 1. The selected mine sites (adapted from [11]).

\begin{tabular}{llllll}
\hline $\begin{array}{l}\text { Mine } \\
\text { site }\end{array}$ & Location & $\begin{array}{l}\text { Production } \\
(\mathrm{Cu} \text { tpa) }\end{array}$ & $\begin{array}{l}\text { Calculated } \\
\text { required } \\
\text { fuel }\left(\mathrm{m}^{3} \mathrm{pa}\right)\end{array}$ & $\begin{array}{l}\text { Ambient } \\
\text { temperature } \\
(\text { High/Low) }\end{array}$ & $\begin{array}{l}\text { Main electricity } \\
\text { generation }\end{array}$ \\
\hline A & Canada & 6400 & 5321 & $24^{\circ} \mathrm{C} /-23^{\circ} \mathrm{C}$ & Hydropower $(98 \%)$ \\
B & Australia & 53,000 & 5150 & $35^{\circ} \mathrm{C} / 5^{\circ} \mathrm{C}$ & $\mathrm{Coal}(80.8 \%)$ \\
$\mathrm{C}$ & Zambia & 18,000 & 4742 & $34^{\circ} \mathrm{C} / 10^{\circ} \mathrm{C}$ & Hydropower $(85 \%)$ \\
D & Poland & 74,000 & 24,720 & $25^{\circ} \mathrm{C} /-3^{\circ} \mathrm{C}$ & Coal $(80 \%)$ \\
\hline
\end{tabular}

location, resulting is distances between 400 and $2300 \mathrm{~km}$, transportation to the mine site, and use of the diesel (Fig. 2). The biodiesel scenario includes regional cultivation of microalgae (with smelter offgas), subsequent microalgae harvesting, production of biodiesel (lipid extraction and transesterification), biodiesel transport to the mine site, and the end-use as biodiesel blend.

The microalgae cultivation facilities were selected based on a comparison of options, as shown in Table 4. The selected top-lit, covered microalgae production ponds operate at $1 \mathrm{~m}$ depth, providing a good areal production rate and allowing for increased residence time of applied $\mathrm{CO}_{2}$ rich off-gas [45]. This design is based on previous models that used smelter furnace off-gas to both heat (when needed), agitate, and supply $\mathrm{CO}_{2}$, which showed that utilizing the $24 \mathrm{~m}^{3} \mathrm{~s}^{-1}$ of furnace off-gas $\left(6 \% \mathrm{CO}_{2}\right.$ on average $) 180$ tanks ( $50 \mathrm{~m}$ long, 5 wide and $1 \mathrm{~m}$ deep) could be supported $[33,46]$. The gas-lift design and off-gas application rate used in this model is based on extensive laboratory results $[45,47,48]$. The various stages from microalgae cultivation to biodiesel production are assumed to be carried out at the smelter site to avoid additional transportation.

The selection of an appropriate harvesting method of cultivated microalgae includes considerations of cost, biomass contamination, reusability of the cultivation media, processing time, scalability, recovery and concentration factor [51]. As such, several options are compared in Table 5, and based on the

Table 2. Vehicle inventory (adapted from [11]).

\begin{tabular}{lllll}
\hline Equipment & \multicolumn{3}{l}{ Mine site } & \\
\cline { 2 - 5 } & $\mathrm{A}$ & $\mathrm{B}$ & $\mathrm{C}$ & $\mathrm{D}$ \\
\hline Haulage Truck & 8 & 10 & 10 & 30 \\
LHD & 10 & 13 & 12 & 43 \\
Jumbo Drill & 4 & 2 & 3 & 16 \\
Production Drill & 3 & 2 & 2 & 8 \\
Bolters & 8 & 5 & 6 & 33 \\
Explosives Vehicle & 3 & 4 & 4 & 19 \\
Personnel Carrier & 26 & 50 & 15 & 54 \\
Miscellaneous $^{\mathrm{a}}$ & 55 & 30 & 50 & 83 \\
\hline
\end{tabular}

\footnotetext{
a Miscellaneous includes minecats, forklifts, loaders, pickups,
} etc. requirements, a two-stage system consisting of sub merged microfiltration followed by centrifugation was selected. The system requires $0.84 \mathrm{kWh} \mathrm{m}^{-3}$ of culture processed [52]. The model was developed such that the harvesting system is run upon reaching a biomass concentration of $1 \mathrm{~g} / \mathrm{L}$, at which point $80 \%$ of the pond volume was harvested and the water recycled. The system is then replenished with the necessary water, nitrogen and phosphorus to account for the losses to the harvested concentrate.

Following harvesting, extraction is required to remove the lipid fraction as a feedstock for biodiesel production. To avoid additional dewatering and drying stages, the wet biomass processing method proposed by Sathish and Sims [55] was adopted. The method utilizes an eight stage process and uses inputs of sulphuric acid $\left(2.45 \mathrm{~kg} \mathrm{~kg}^{-1} \mathrm{algae}, \mathrm{dw}\right)$, sodium hydroxide $\left(2.00 \mathrm{~kg} \mathrm{~kg}_{\text {algae, dw }}^{-1}\right)$, water $\left(70 \mathrm{~kg} \mathrm{~kg}_{\text {algae,dw }}^{-1}\right)$, and hexane ( $\left.32.75 \mathrm{~kg} \mathrm{kgalgae}^{-1} \mathrm{dw}\right)$. It was assumed that the evaporated hexane at the end of the process can be recovered and recycled at an efficiency of $90 \%$. Electricity requirements for heating, centrifugation, and evaporation were estimated to be $14.7 \mathrm{kWh}$ $\mathrm{kg}_{\text {algae,dw. }}^{-1}$.

The final stage of biodiesel production is transesterification, where the extracted lipids are reacted with methanol in the presence of a catalyst to produce methyl esters (biodiesel) and glycerol $[56,57]$. For this model a sodium hydroxide catalyst was utilized as an efficient and low cost catalyst [58]. An existing process for soy biodiesel production provided in the LCA software was adapted to the microalgal lipid input [59].

Table 3. Electricity generation breakdown of the four mine sites.

\begin{tabular}{lllll}
\hline \multirow{2}{*}{$\begin{array}{l}\text { Electricity generation } \\
\text { method }\end{array}$} & \multicolumn{4}{l}{ Mine site } \\
\cline { 2 - 5 } & $\mathrm{A}^{1}$ & $\mathrm{~B}^{2}$ & $\mathrm{C}^{3}$ & $\mathrm{D}^{4}$ \\
\hline Coal & $<1 \%$ & $81 \%$ & $8 \%$ & $80 \%$ \\
Natural gas & $<1 \%$ & $2 \%$ & $7 \%$ & $7 \%$ \\
Hydropower & $97 \%$ & $5 \%$ & $85 \%$ & - \\
Solar & - & $5.1 \%$ & - & - \\
Wind & $2 \%$ & $5.3 \%$ & - & $13 \%$ \\
Biomass & $<1 \%$ & $1.6 \%$ & - & - \\
Intensity factor & 3.4 & 743.7 & 128.1 & 801.8 \\
$\quad\left(\mathrm{~g} \mathrm{CO}_{2} \mathrm{kWh}^{-1}\right)$ & & & & \\
\hline${ }^{1}{ }_{[41],{ }^{2}[42],{ }^{3}[43],{ }^{4}[44] .}$ & & &
\end{tabular}




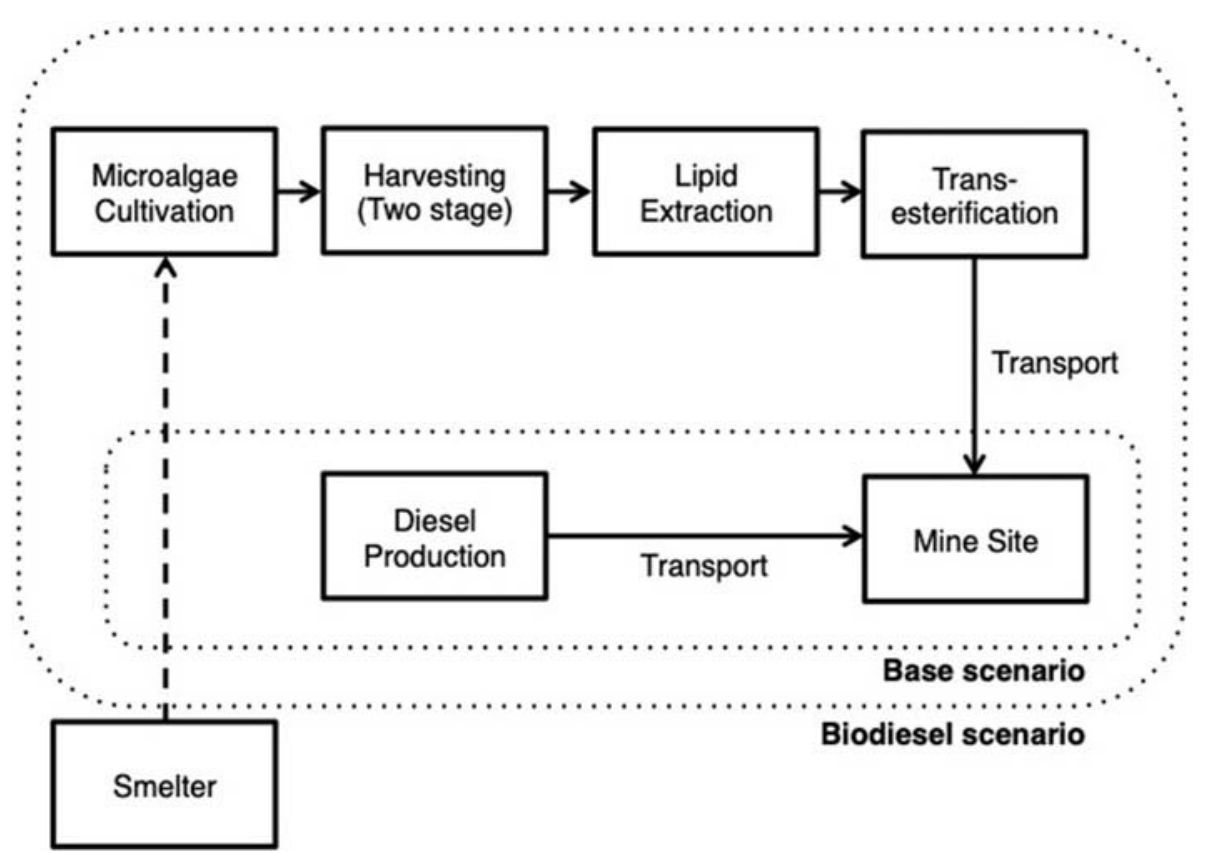

Fig. 2. General process overview with either fossil fuel diesel or biodiesel-blend operations.

\subsection{Microalgae biodiesel production}

The mine sites selected for evaluation represent a wide range of climates, as can be seen from average monthly temperatures, collected from climate-data. org, shown in Fig. 3. Another important locational and seasonal variable is solar irradiation, and these values were calculated using the ASHRAE Clear Sky Model [60], which is commonly used for engineering approximations [54]. Solar irradiation $\left(I_{h}, \mathrm{~W} \mathrm{~m}{ }^{-2}\right)$ was subsequently calculated using Equation (1):

$I_{h}=(C+\sin \beta)\left(\frac{A}{\mathbf{e}^{B / \sin \beta}}\right)$

where $A$ is the apparent solar irradiation $\left(\mathrm{W} \mathrm{m}^{-2}\right)$, $B$ is the atmospheric extinction coefficient (unitless), $C$ is the ratio of diffuse radiation on a horizontal surface to the direct normal irradiation (unitless) and $\beta$ is the solar altitude angle (radians). Monthly average values of $A, B$, and $C$ were used, and $\beta$ was calculated according to Equation (2) [61]: $\sin \beta=\sin \delta \sin \lambda+\cos \delta \cos \lambda \cos \omega$

where $\delta$ is the solar declination angle (radians), $\lambda$ is the latitude (radians), and $\omega$ is the hour angle (radians). Hourly values were calculated and averaged over a month for the growth model input. Comparing the model output to measured datasets available online provided an average monthly irradiation within $10 \%$ of the measured values (data not included).

Using the climatic information, as the major determining factor for microalgae growth rate the temperature of the microalgae ponds $(50 \mathrm{~m} \times 5 \mathrm{~m} \times 1 \mathrm{~m})$ was calculated, this took into account evaporative, convective, conductive heat losses, and heat addition through the application of off-gas and solar irradiation. For a detailed description of the model development refer to Laamanen et al. [33].

\subsection{Microalgae selection}

It is important to highlight that trace acidic gas components (mainly $\mathrm{SO}_{2}$ ) in the applied off gas

Table 4. Comparison between microalgae cultivation options.

\begin{tabular}{lllll}
\hline Option & $\begin{array}{l}\text { Areal volume } \\
\left(\mathrm{m}^{3} \mathrm{~m}^{-2}\right)\end{array}$ & $\begin{array}{l}\text { Areal productivity } \\
\left(\mathrm{g} \mathrm{m}^{-2} \text { day }^{-1}\right)\end{array}$ & $\begin{array}{l}\text { Relative } \\
\text { Cost }\end{array}$ & $\begin{array}{l}\text { Reference } \\
\text { Raceway pond }\end{array}$ \\
\hline Raceway pond & 0.18 & 10 & Low & Low \\
Flat panel photobioreactor & 0.2 & 20 & High & {$[49]$} \\
Tubular photobioreactor & 0.7 & 42 & High & {$[50]$} \\
Deep pond (used in this assessment) & 0.65 & 65 & Medium & {$[50]$} \\
\hline
\end{tabular}


Table 5. Comparison between microalgae harvesting options.

\begin{tabular}{|c|c|c|c|c|c|}
\hline Option & Recovery (\%) & $\begin{array}{l}\text { Concentration } \\
\text { Factor }(-)\end{array}$ & $\begin{array}{l}\text { Exiting } \\
\text { Concentration } \\
\left(\mathrm{g} \mathrm{L}^{-1}\right)\end{array}$ & $\begin{array}{l}\text { Energy } \\
\text { requirements } \\
\left(\mathrm{kWh} \mathrm{m}^{-3}\right)\end{array}$ & Reference \\
\hline Centrifugation (high recovery) & 94 & - & - & 20 & [53] \\
\hline Centrifugation (low energy) & 17 & - & - & 0.8 & [53] \\
\hline Electrolytic Flotation & 52.2 & 52.8 & 29.03 & 4.96 & [54] \\
\hline $\begin{array}{l}\text { Two stage (filtration-centrifugation) } \\
\text { (used in this assessment) }\end{array}$ & 95 & 55 & 22 & 0.84 & [52] \\
\hline
\end{tabular}

would reduce the $\mathrm{pH}$ of the microalgae tanks down to $\mathrm{pH} 2.5-3$, and to avoid significant additional costs for neutralization, typically through lime addition, we chose to utilize acidophilic microalgae [62].

The acidophilic species Chlamydomonas acidophila identified from the Tinto River in Spain [63] with optimal growth at $\mathrm{pH} 2.6-3$ and $17.5^{\circ} \mathrm{C}$, can survive up to $27^{\circ} \mathrm{C}$ [64]. Under culture conditions that will occur from sparging in smelter furnace off gas $\left(\mathrm{pH} 2.5\right.$ with $\left.5 \% \mathrm{CO}_{2}\right), C$. acidophila achieved production of $10 \mathrm{~kg} / \mathrm{m}^{3}$ of dry weight biomass per growth cycle [63], with a lipid content of $54.7 \%[65]$.
The minimum temperature acceptable level of growth was taken as $1.5^{\circ} \mathrm{C}$, which is based on an average of 10 microalgae species [66]. Microalgae growth can be calculated as a function of pond temperature using Equations (3) and (4) [66]:

$\mu_{\max }=\left\{\begin{array}{l}0 \text { for } T_{p}<T_{\min } \\ \mu_{\mathrm{opt}} \cdot \phi(T) \text { for } T_{\min }<T_{p}<T_{\max } \\ 0 \text { for } T_{p}>T_{\max }\end{array}\right.$

where $\mu_{\max }$ is the maximum specific growth rate at temperature $T_{p}\left(\right.$ day $\left.^{-1}\right)$, and the temperature dependent growth rate can be calculate from:

$\phi(T)=\frac{\left(T_{p}-T_{\max }\right)\left(T_{p}-T_{\min }\right)^{2}}{\left(T_{\mathrm{opt}}-T_{\mathrm{min}}\right)\left[\left(T_{\mathrm{opt}}-T_{\mathrm{min}}\right)\left(T_{p}-T_{\mathrm{opt}}\right)-\left(T_{\mathrm{opt}}-T_{\max }\right)\left(T_{\mathrm{opt}}+T_{\min }-2 T_{p}\right)\right]}$

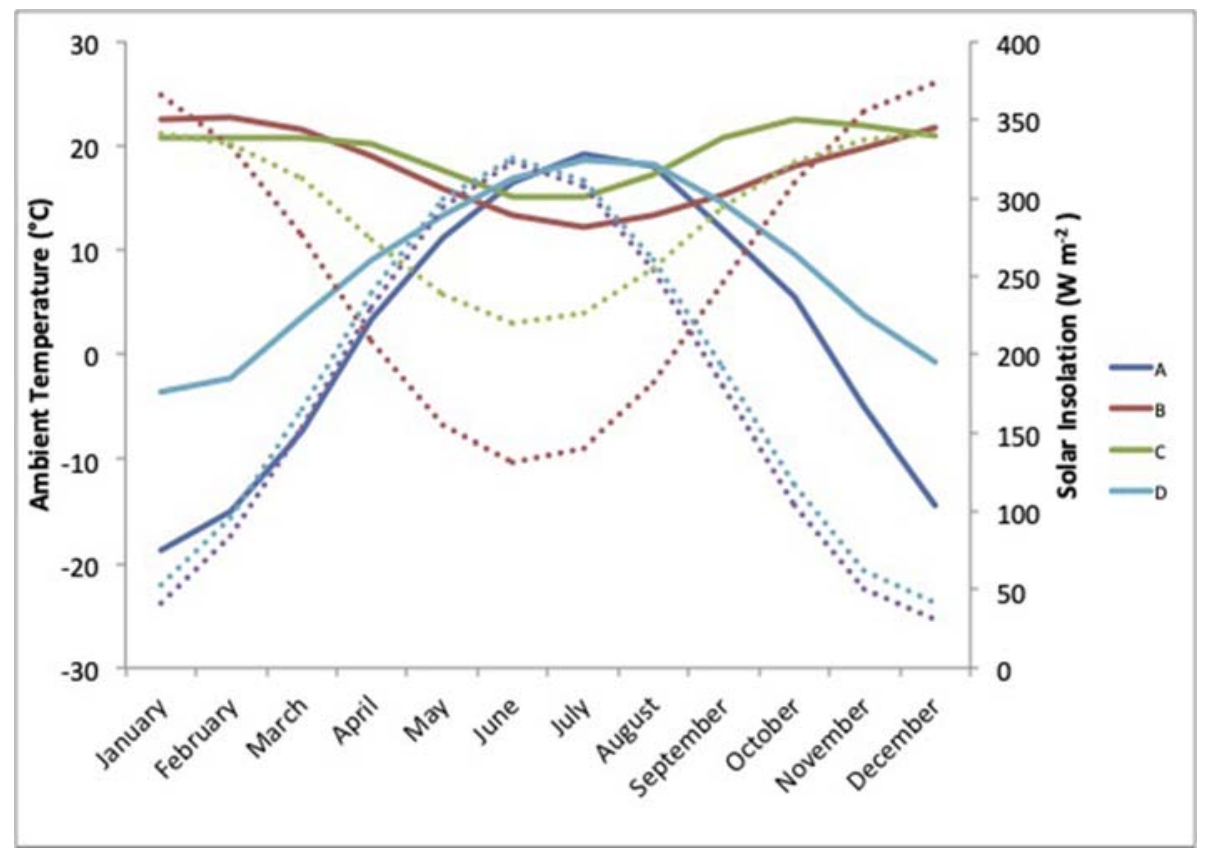

Fig. 3. Ambient air temperature (solid line) and solar insolation (dotted line) for the four mine sites A (Canada), B (Australia), C (Zambia), and D (Poland). 


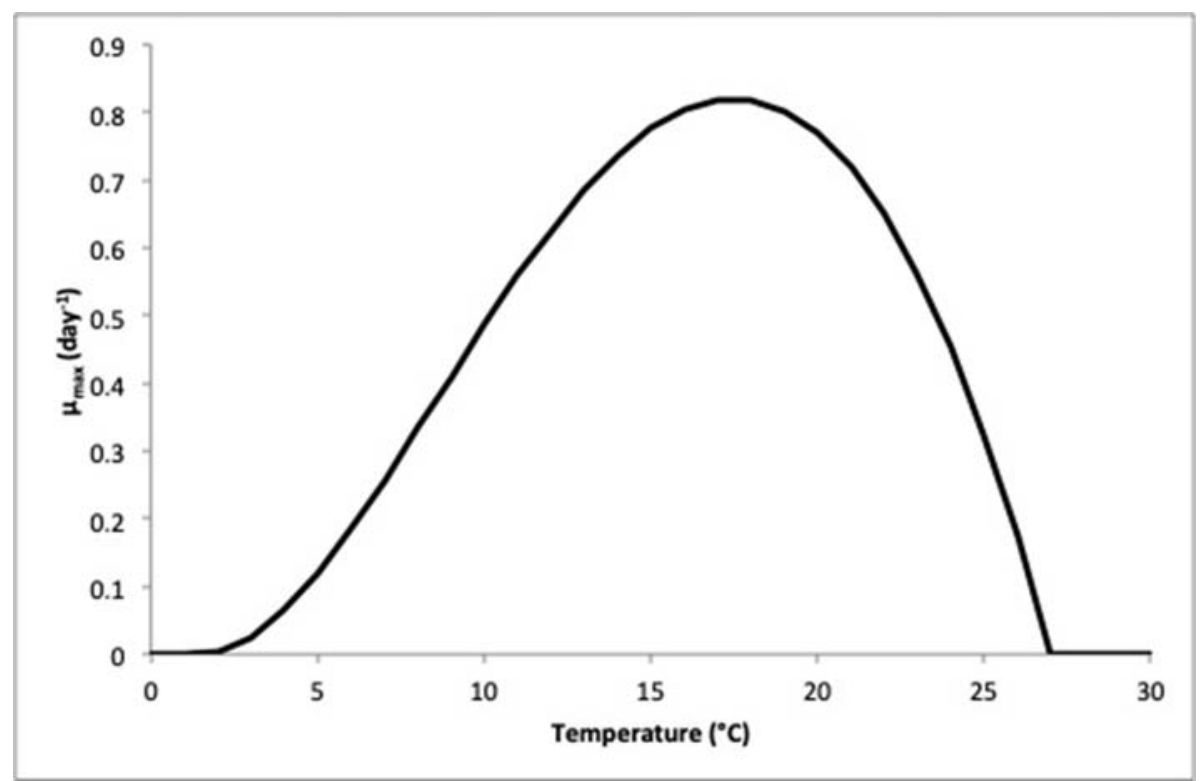

Fig. 4. The modelled temperature dependent specific growth rate of $C$. acidophila.

$T_{p}$ is the operating temperature of the pond, and $T_{\max }, T_{\min }$ and $T_{\mathrm{opt}}$ are respectively the minimum, maximum, and optimal microalgae growth temperatures $\left({ }^{\circ} \mathrm{C}\right)$. Growth rate as a function of temperature is shown in Fig. 4.

\subsection{Life cycle assessment (LCA) modelling}

The LCA modeling was performed using the TRACI (Tool for the Reduction and Assessment of
Chemical and Other Environmental Impacts) 2.1 methodology within GaBi Solutions software [59]. The software was used to calculate emissions that contribute to global warming, acidification, eutrophication and human toxicity potentials, and was developed from one used to assess underground metal ore mining [11]. This model was verified by predicting $\mathrm{CO}_{2}$ emissions to within $\pm 5.6 \%$ of those reported by the mines. The LCA model was

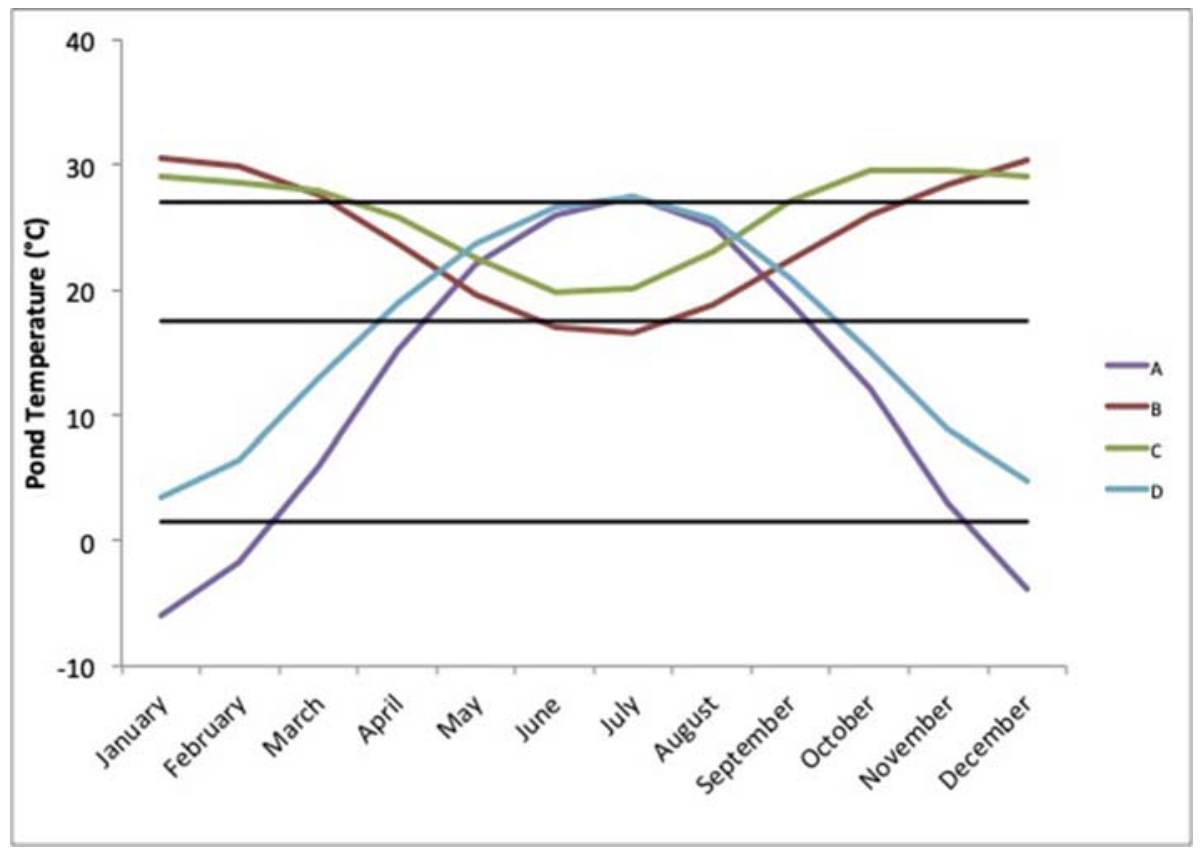

Fig. 5. Modelled microalgae cultivation pond temperatures at the four regional mine sites. 


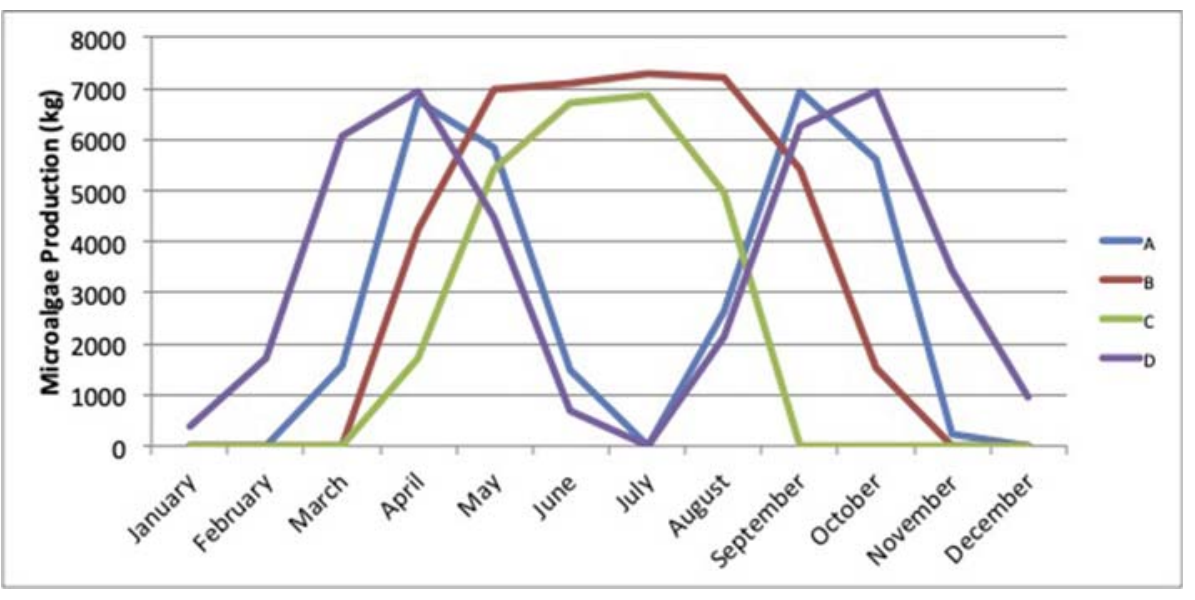

Fig. 6. Monthly microalgae production at the four regional smelter sites.

expanded to include production, transportation, and end-use of both types of diesel fuel.

\section{Results and discussion}

\subsection{Microalgae biodiesel production}

The model was used to calculate the monthly pond temperature (Fig. 5) along with key temperatures for the selected microalgae growth (maximum $\left(27^{\circ} \mathrm{C}\right)$, optimum $\left(17.5^{\circ} \mathrm{C}\right)$ and minimum $\left(1.5^{\circ} \mathrm{C}\right)$.

The distribution of the heat transfer terms and their influence on estimated monthly temperature of the algae growth tanks show that despite having the ponds covered, surface heat losses are relatively high due to both convective ( $q_{\text {conv }}$ ) and evaporative $\left(q_{\text {evap }}\right)$ losses. With respect to heat addition, the gain from sparging in off gas ( $\left.q_{\text {offgas }}\right)$ is reasonably constant throughout the year, but solar energy has a significant influence on determining the operational temperature of the microalgae growth tanks (data not included).

Using the microalgae C. acidophila, the monthly temperatures can be used to estimate biomass production (Fig. 6). Values of zero productivity represent months where the temperature was either below the minimum temperature (winter of site $\mathrm{A}$ ) or above the maximum temperature (summer of sites $B$ and $C)$.

Site B (Australia) showed the highest biomass productivity in July ( $7275 \mathrm{~kg}$ of biomass produced in a month), whereas site D (Poland) could produce 11 months a year - coincidentally the result of these monthly variations were a very similar annual production between these sites. Site D would be able to produce 40.0 tonnes of microalgae (dry weight) per year while site $B$ could produce 39.7 tonnes $\mathrm{yr}^{-1}$. While site A (Canada, 31.1 tonnes $\mathrm{yr}^{-1}$ ) and site C (Zambia, 25.7 tonnes $\mathrm{yr}^{-1}$ ) were able to produce smaller quantities of microalgae per year based on the climates being too variable and hot, respectively.

Due to the elevated temperature the Zambian site (site C) shows the shortest growing season of five months. However, it is important to note that here is potential for improvement by bioprospecting for a regional microalgae species suited for the operational temperature profile, while also screening to ensure a high lipid productivity and an acidophilic or acid tolerant cultivation behaviour [62].

\subsection{Mine site biodiesel supply}

Based on calculated annual microalgae production potential, the maximum biodiesel supply to

Table 6. Fuel requirements for the regional mine sites.

\begin{tabular}{lllll}
\hline & Mine site & & C & \\
\cline { 2 - 5 } & A & B & 959,950 & D \\
\hline Annual ore production $(\mathrm{t})$ & $1,095,000$ & $1,000,100$ & 4.94 & $8,000,000$ \\
Diesel use (L/t ore) & 4.86 & 5.15 & 4742.20 & 3.09 \\
Annual required diesel $\left(\mathrm{m}^{3}\right)$ & 5321.70 & 5150.50 & 1434.50 & 24,720 \\
Annual biodiesel production $\left(\mathrm{m}^{3}\right)$ & 1737.20 & 2218.60 & 30.2 & 2234.20 \\
Average blend $(\%)$ & 32.6 & 43.0 & 9.0
\end{tabular}

The relatively low blend achievable at site D (Poland), despite having the highest potential annual microalgae production, is due to an ore production rate about eight times greater than sites A, B, and C. 
Table 7. The global warming potential ( $\mathrm{CO}_{2}$ eq. yr-1) for the production of diesel and biodiesel for each site. Biodiesel blend operations represent the maximum biodiesel produced at each site.

\begin{tabular}{|c|c|c|c|c|}
\hline \multirow[t]{2}{*}{ Process } & \multicolumn{4}{|c|}{ Mine site } \\
\hline & A & B & $\mathrm{C}$ & $\mathrm{D}$ \\
\hline \multicolumn{5}{|c|}{ Diesel operations (t $\mathrm{CO}_{2}$ eq. $\mathrm{yr}^{-1}$ ) } \\
\hline Diesel production & 1889 & 2443 & 1747 & 26,678 \\
\hline $\begin{array}{l}\text { Smelter off-gas } \\
\text { (uncaptured) }\end{array}$ & 8187 & 10,649 & 7296 & 11,020 \\
\hline Total & 10,076 & 13,092 & 9043 & 37,698 \\
\hline \multicolumn{5}{|c|}{ Biodiesel operations ( $\mathrm{C}_{2}$ eq. $\mathrm{yr}^{-1}$ ) } \\
\hline Utilizing maximum blend & B30 & B40 & B30 & B9 \\
\hline Algae growth & 21 & 1412 & 156 & 1560 \\
\hline Harvesting & 59 & 3952 & 437 & 4369 \\
\hline Lipid extraction & 674 & 45,475 & 5028 & 50,265 \\
\hline Biodiesel production & 2248 & 3088 & 2004 & 3134 \\
\hline Diesel production & 1289 & 1399 & 1192 & 10,076 \\
\hline Total & 4291 & 55,326 & 8817 & 69,404 \\
\hline
\end{tabular}

each mine site could be calculated. By using the total required fuel for each mine, based on diesel consumed per tonne of ore mined, the average biodiesel blend that could be utilized onsite was estimated (Table 6).

\subsection{Environmental impacts}

It was assumed that the smelter off-gas $\mathrm{CO}_{2}$ from all four sites would be used at a rate of $1.8 \mathrm{~g}_{\mathrm{CO} 2} /$ $g_{\text {biomass }}$ when microalgae are being produced. Whilst $\mathrm{CO}_{2}$ consumption rates have not been reported for C. acidophila, Euglena gracilis and Coccomyxa sp., grown at low $\mathrm{pH}$ can consume $2.4-4.6 \mathrm{~g}$ of $\mathrm{CO}_{2}$ per $\mathrm{g}$ of dry weight biomass [67]. As these values are well above the $\mathrm{CO}_{2}$ consumption rate modelled in this study, the values for $\mathrm{CO}_{2}$ capture are potentially underestimates for the maximum capture possible. The carbon capture from the smelter off-gas due to microalgae grown would result in potential mitigation of $8187 \mathrm{t} \mathrm{CO}_{2}$ eq. $\mathrm{yr}^{-1}$, $10,649 \mathrm{t} \mathrm{CO}_{2}$ eq. $\mathrm{yr}^{-1}, 7296 \mathrm{t} \mathrm{CO}_{2}$ eq. $\mathrm{yr}^{-1}$, and $11,020+\mathrm{CO}_{2}$ eq. $\mathrm{yr}^{-1}$ of global warming potential for

Table 8. The global warming potential $\left(t \mathrm{CO}_{2}\right.$ eq. $\left.\mathrm{yr}^{-1}\right)$ for transport of diesel and biodiesel for each regional mine site.

\begin{tabular}{|c|c|c|c|c|}
\hline \multirow[t]{2}{*}{ Process } & \multicolumn{4}{|c|}{ Mine site } \\
\hline & A & B & $\mathrm{C}$ & $\mathrm{D}$ \\
\hline Refinery to mine $(\mathrm{km})$ & 835 & 700 & 2300 & 425 \\
\hline \multicolumn{5}{|c|}{ Diesel operations ( $\mathrm{t} \mathrm{CO}$ eq. $\mathrm{yr}^{-1}$ ) } \\
\hline Diesel transportation & 5586 & 7076 & 20,900 & 88,286 \\
\hline Total & 5586 & 7076 & 20,900 & 88,286 \\
\hline \multicolumn{5}{|c|}{ Biodiesel operations (t $\mathrm{CO}_{2}$ eq. $\mathrm{yr}^{-1}$ ) } \\
\hline Maximum available blend & B30 & B40 & B30 & B9 \\
\hline Biodiesel transportation & 76 & 106 & 1203 & 498 \\
\hline Diesel transportation & 3813 & 4083 & 14,269 & 79,883 \\
\hline Total & 3889 & 4189 & 15,472 & 80,381 \\
\hline
\end{tabular}

the smelters associated with sites A, B, C, and D, respectively.

In addition to mitigation of $\mathrm{CO}_{2}$ at the smelter, the global warming potential ( $\mathrm{C}_{2}$ eq.) associated with the production of each fuel type was analyzed. Emissions from the production of diesel fuel were calculated using the regional diesel production processes available within the LCA software. The associated impact of the diesel production also includes fuel transportation from the nearest refinery to the mine site, which ranged between 400 and $2300 \mathrm{~km}$ (Table 7). In Table 7, for comparison between diesel and biodiesel operations, the $\mathrm{CO}_{2}$ eq. emissions released in the form of smelter off gas is equivalent to the amount that would be consumed with the production of biodiesel.

An import consideration is the advantage of regional biodiesel production and the associated reduction of emissions that are required to transport petrochemical diesel. Transportation emissions (Table 8) were calculated for petrochemical diesel based on the distance travelled to the nearest diesel refinery for each mine site. For the purposes of this study, biodiesel transportation was calculated based on a $10 \mathrm{~km}$ distance as the biodiesel due to location of the production plant on the smelter's property. This led to decreased $\mathrm{CO}_{2}$ eq. emissions across all four mine sites for the transportation of fuel for onsite use.

Table 9 shows that the production of biodiesel and the use of a B30 blend at both mine sites A and $C$ results in reduced impacts across all four emissions categories examined compared to the use of exclusively diesel fuel. The lipid extraction process continues to produce high levels of $\mathrm{CO}_{2}$ eq. in areas that use fossil fuels for electric energy generation. Until these regions begin to transition to renewable energy generation methods, alternative processes for lipid extraction need to be further investigated to reduce emissions from biodiesel production at mine sites B and D. This finding is consistent with the study by Bharathan et al. [68] which showed that for BEV usage underground to be beneficial, from an overall global warming potential perspective, low carbon emitting regional electricity generation is required.

A decrease in human toxicity potential was reported for all four mine sites. While the human toxicity potential does not determine guidelines for ventilation in underground mines, the results suggest that there is an opportunity to decrease ventilation use, and therefore costs. Differences in emissions from biodiesel are not only restricted to the ratio of biodiesel to diesel [69], but also to engine temperature [17], load and speed [70]. 
Table 9. Summarized emissions of diesel and biodiesel operations from production, transport, and fuel use.

\begin{tabular}{|c|c|c|c|c|}
\hline \multirow[t]{2}{*}{ Category } & \multicolumn{4}{|c|}{ Mine site } \\
\hline & A & B & $\mathrm{C}$ & $\mathrm{D}$ \\
\hline \multicolumn{5}{|c|}{ Global warming potential (t $\mathrm{CO}_{2}$ eq. $\mathrm{yr}^{-1}$ ) } \\
\hline Diesel operations & 32,761 & 121,260 & 67,567 & 793,650 \\
\hline Biodiesel blend operations & 25,472 & 148,866 & 59,783 & 797,045 \\
\hline Difference & $-22.5 \%$ & $+22.8 \%$ & $-11.5 \%$ & $+0.43 \%$ \\
\hline \multicolumn{5}{|c|}{ Acidification potential ( $\mathrm{t} \mathrm{SO}$ eq. $\mathrm{yr}^{-1}$ ) } \\
\hline Diesel operations & 328 & 1099 & 662 & 7400 \\
\hline Biodiesel blend operations & 296 & 1388 & 536 & 7491 \\
\hline Difference & $-9.7 \%$ & $+26.3 \%$ & $-18.9 \%$ & $+1.2 \%$ \\
\hline \multicolumn{5}{|c|}{ Eutrophication potential ( $\mathrm{t} \mathrm{N}$ eq. $\mathrm{yr}^{-1}$ ) } \\
\hline Diesel operations & 43.1 & 82.9 & 57.8 & 582.9 \\
\hline Biodiesel blend operations & 40.5 & 105.4 & 55 & 595.1 \\
\hline Difference & $-6.1 \%$ & $+27.3 \%$ & $-4.8 \%$ & $+2.1 \%$ \\
\hline \multicolumn{5}{|c|}{ Human toxicity potential (CTUh $\mathrm{yr}^{-1}$ ) } \\
\hline Diesel operations & 4.54 & 5.94 & 8.12 & 44.8 \\
\hline Biodiesel blend operations & 3.80 & 5.43 & 6.4 & 43.2 \\
\hline Difference & $-16.2 \%$ & $-8.7 \%$ & $-21.0 \%$ & $-3.6 \%$ \\
\hline
\end{tabular}

The differences in emissions and varying regional regulations means specific testing at individual sites would need to be conducted to ensure all contaminants are below legal limits for long-term human working conditions. As such, while not assessed in this study, it could be expected that further decreases in energy consumption (and associated improvements in environmental impact) could be achieved through reduced ventilation requirements when biodiesel is used underground.

\section{Conclusions}

An LCA was conducted to compare the global warming, acidification, eutrophication, and the human toxicity potentials of two different mining scenarios (diesel vs biodiesel blends) based in four regionally distinct underground metal ore mines. Our primary goal was to examine the possibility of producing biodiesel blend from microalgal biomass cultivated using smelter off gas $\left(6 \% \mathrm{CO}_{2}\right)$.

From our findings, the cultivation of $\mathrm{C}$. acidophila using smelter off gas as a $\mathrm{CO}_{2}$ source was able to produce enough biodiesel annually to supply mine site A (Canada) and C (Zambia) with B30, mine site B (Australia) with B40, while mine site D (Poland) could use B9, due to its much higher ore production capacity.

Mine sites A (Canada) and C (Zambia), with their regional electricity generation coming largely from renewable sources, were capable of reducing overall emissions to their process by utilizing regionally produced microalgal biodiesel in a $30 \%$ blend instead of pure diesel fuel in all four potentials examined. They showed reductions in global warming potential of $22.5 \%$ (A) and $11.5 \%$ (C), acidification potential of $9.1 \%$ (A) and $18.9 \%$ (C), eutrophication potential of $6.1 \%(\mathrm{~A})$ and $4.8 \%(\mathrm{C})$, and human toxicity potential of $16.2 \%$ (A) and $21.0 \%$ (C). While the environmental impact was tied to regional electricity generation, all sites showed a decrease in human toxicity potential.

Although beyond the scope of this study, all sites could potentially benefit from reduced ventilation requirements through the use of biodiesel blends. That is, the requirement to remove emissions could be reduced through the use of biodiesel blends, but the overall requirements are determined by health and safety regulations that vary by location. Other underground operations, mine and ventilation system design, and climatic considerations will also influence requirements.

Overall, the utilization of microalgae biodiesel blends to replace pure petrochemical diesel represents a promising route for the mining industry to both transition to the use of BEVs and maximise its return on investment in existing machinery.

The outcomes of this study demonstrate the significant potential for utilizing regionally produced biodiesel underground. In further work, the described concept could focus on biodiesel use in other equipment (including utility vehicles and generators) and also consider different mining operations, in terms of ore type and mine design. This would provide valuable information to the industry to help it elucidate opportunities for an improved environmental footprint. 


\section{Conflicts of interest}

None declared.

\section{Ethical statement}

The authors state that the research was conducted according to ethical standards.

\section{Funding}

This work was supported by the Mitacs Accelerate Program partnered with Sudbury Integrated Nickel Operations, grant numbers IT11703 and IT14311.

\section{References}

[1] Gorman MR, Dzombak DA. A review of sustainable mining and resource management: transitioning from the life cycle of the mine to the life cycle of the mineral. Resour Conserv Recycl 2018;137:281-91. https://doi.org/10.1016/j.resconrec. 2018.06.001.

[2] Ranängen $\mathrm{H}$, Lindman A. A path towards sustainability for the Nordic mining industry. J Clean Prod 2017;151:43-52. https://doi.org/10.1016/j.jclepro. 2017.03.047.

[3] International Council on Mining \& Metals. ICMM 10 principles. https://www.icmm.com/en-gb/about-us/memberrequirements/mining-principles. [Accessed 24 August 2021].

[4] Farjana SH, Huda N, Mahmud MAP, Saidur R. A review on the impact of mining and mineral processing industries through life cycle assessment. J Clean Prod 2019;231: 1200-17. https://doi.org/10.1016/j.jclepro.2019.05.264.

[5] Tost M, Hitch M, Chandurkar V, Moser P, Feiel S. The state of environmental sustainability considerations in mining. J Clean Prod 2018;182:969-77. https://doi.org/10.1016/ j.jclepro.2018.02.051.

[6] Paraszczak J, Svedlund E, Fytas K, Laflamme M. Electrification of loaders and trucks-a step towards more sustainable underground mining. Renewable Energy Power Qual J 2014: 81-6. https://doi.org/10.24084/repqi12.240.

[7] Jacobs W, Hodkiewicz MR, Bräunl T. A cost-benefit analysis of electric loaders to reduce diesel emissions in underground hard rock mines. IEEE Transactions Ind Appl 2015;51: 2565-73. https://doi.org/10.1109/TIA.2014.2372046.

[8] Gönen A. Ventilation requirements for today's mechanized underground metal mines. Int J Adv Res Eng 2018;4:7-10. https://doi.org/10.24178/ijare.2018.4.1.07.

[9] Reşitoğlu İA, Altinişik K, Keskin A. The pollutant emissions from diesel-engine vehicles and exhaust aftertreatment systems. Clean Technol Environ Pol 2015;17:15-27. https:// doi.org/10.1007/s10098-014-0793-9.

[10] Moreau K, Bose R, Shang H, Scott JA. Automation technology to increase productivity and reduce energy consumption in deep underground mining operations. Comer Ind Madera (CIM) J 2019;10:115-24.

[11] Moreau K, Laamanen CA, Bose R, Shang H, Scott JA. Life cycle assessment to demonstrate how automation improves the environmental performance of an underground mining operation. J Sustainable Min 2020;19:182-94. https://doi.org/ 10.46873/2300-3960.1016.

[12] Nieto A, Schatz RS, Dogruoz C. Performance analysis of electric and diesel equipment for battery replacement of tethered LHD vehicles in underground mining. Min Technol 2020;129:22-9. https://doi.org/10.1080/25726668.2020.1720371.

[13] Schatz RS, Nieto A, Lvov SN. Long-term economic sensitivity analysis of light duty underground mining vehicles by power source. Int J Min Sci Technol 2017;27:567-71. https:// doi.org/10.1016/j.ijmst.2017.03.016.
[14] Aaldering LJ, Song CH. Tracing the technological development trajectory in post-lithium-ion battery technologies: a patent-based approach. J Cleaner Prod 2019;241:118343. https://doi.org/10.1016/j.jclepro.2019.118343.

[15] Schatz RS, Nieto A, Dogruoz C, Lvov SN. Using modern battery systems in light duty mining vehicles. Int J Min Reclam Environ 2015;25:243-65. https://doi.org/10.1080/ 17480930.2013.866797.

[16] de la Vergne JN. Hard rock miner's handbook. $5^{\text {th }}$ ed. Stantec Consulting; 2008.

[17] Lutz EA, Reed RJ, Lee VST, Burgess JL. Comparison of personal diesel and biodiesel exhaust exposures in an underground mine. J Occup Environ Hyg 2017;14:102-9. https://doi.org/10.1080/15459624.2017.1285488.

[18] Bugarski AD, Janisko SJ, Cauda EG, Patts LD, Hummer JA, Westover $\mathrm{C}$, et al. Aerosols and criteria gases in an underground mine that uses FAME biodiesel blends. Ann Occup Hyg 2014;58:971-82. https://doi.org/10.1093/annhyg/ meu049.

[19] Ben-Iwo J, Manovic V, Longhurst P. Biomass resources and biofuels potential for the production of transportation fuels in Nigeria. Renew Sustain Energy Rev 2016;63:172-92. https://doi.org/10.1016/j.rser.2016.05.050.

[20] Wolinetz M, Hein M, Moawad B. Biofuels in Canada 2019 tracking biofuel consumption, feedstocks and avoided greenhouse gas emissions. 2019.

[21] Gouveia L, Oliveira AC. Microalgae as a raw material for biofuels production. J Ind Microbiol Biotechnol 2009;36: 269-74. https://doi.org/10.1007/s10295-008-0495-6.

[22] Islam MA, Heimann K, Brown RJ. Microalgae biodiesel: current status and future needs for engine performance and emissions. Renewable Sustainable Energy Rev 2017;79: 1160-70. https://doi.org/10.1016/j.rser.2017.05.041.

[23] Khalife E, Tabatabaei M, Demirbas A, Aghbashlo M. Impacts of additives on performance and emission characteristics of diesel engines during steady state operation. Prog Energy Combust Sci 2017;59:32-78. https://doi.org/10.1016/j.pecs. 2016.10.001.

[24] Singh D, Subramanian K, Juneja M, Singh K, Singh S, Badola $R$, et al. Investigating the effect of fuel cetane number, oxygen content, fuel density, and engine operating variables on NOx emissions of a heavy duty diesel engine. Environ Prog Sustainable Energy 2017;36:214-21. https://doi.org/ 10.1002/ep.12439.

[25] Islam MA, Rahman MM, Heimann K, Nabi MN Ristovski ZD, Dowell A, et al. Combustion analysis of microalgae methyl ester in a common rail direct injection diesel engine. Fuel 2015;143:351-60. https://doi.org/10.1016/ j.fuel.2014.11.063.

[26] Hossain FM, Nabi MN, Rainey TJ, Bodisco T, Rahman MM, Suara K, et al. Investigation of microalgae HTL fuel effects on diesel engine performance and exhaust emissions using surrogate fuels. Energy Convers Manage 2017;152:186-200. https://doi.org/10.1016/j.enconman.2017.09.016.

[27] Al-lwayzy SH, Yusaf T. Diesel engine performance and exhaust gas emissions using microalgae Chlorella protothecoides biodiesel. Renewable Energy 2017;101:690-701. https://doi.org/10.1016/j.renene.2016.09.035.

[28] Lardon L, Helias A, Sialve B, Steyer JP, Bernard O. Life-cycle assessment of biodiesel production from microalgae. Environ Sci Technol 2009;43:6475-81. https://doi.org/10.1021/ es900705j.

[29] Chungjatupornchai W, Areerat K, Fa-Aroonsawat S. Increased triacylglycerol production in oleaginous microalga Neochloris oleoabundans by overexpression of plastidial lysophosphatidic acid acyltransferase. Microb Cell Fact 2019;18: 53. https://doi.org/10.1186/s12934-019-1104-2.

[30] Desjardins SM, Laamanen CA, Basiliko N, Scott JA. Utilization of lipid-extracted biomass (LEB) to improve the economic feasibility of biodiesel production from green microalgae. Environ Rev 2020;28:325-38. https://doi.org/ 10.1139/er-2020-0004. 
[31] Seyed Hosseini N, Shang H, Ross GM, Scott JA. Comparative analysis of top-lit bubble column and gas-lift bioreactors for microalgae-sourced biodiesel production. Energy Convers Manage 2016;130:230-9. https://doi.org/10.1016/j.enconman. 2016.10.048.

[32] Mohler D, Wilson MH, Kesner S, Schambach JY, Vaughan D, Frazar M, et al. Beneficial re-use of industrial $\mathrm{CO}_{2}$ emissions using microalgae: demonstration assessment and biomass characterization. Bioresour Technol 2019;293:122014. https:// doi.org/10.1016/j.biortech.2019.122014.

[33] Laamanen CA, Shang H, Ross GM, Scott JA. A model for utilizing industrial off-gas to support microalgae cultivation for biodiesel in cold climates. Energy Convers Manage 2014;88:476-83. https://doi.org/10.1016/j.enconman. 2014.08.047.

[34] Mata TM, Martins AA, Caetano NS. Microalgae for biodiesel production and other applications: a review. Renewable Sustainable Energy Rev 2010;14:217-32. https://doi.org/ 10.1016/j.rser.2009.07.020.

[35] Maity JP, Bundschuh J, Chen CY, Bhattacharya P. Microalgae for third generation biofuel production, mitigation of greenhouse gas emissions and wastewater treatment: present and future perspectives-A mini review. Energy 2014;78: 104-13. https://doi.org/10.1016/j.energy.2014.04.003.

[36] Lee KM, Inaba A. Life cycle assessment: best practices of ISO 14040 series. Ministry of Commerce, Industry and Energy, Republic of Korea; 2004.

[37] Stranddorf HK, Hoffmann L, Schmidt A. Impact categories, normalization and weighting in LCA. Environ News 2005;78.

[38] Aslam A, Thomas-Hall SR, Mughal TA, Schenk PM. Selection and adaptation of microalgae to growth in $100 \%$ unfiltered coal-fired flue gas. Bioresour Technol 2017;233:271-83. https://doi.org/10.1016/j.biortech.2017.02.111.

[39] Lara-Gil JA, Senés-Guerrero C, Pacheco A. Cement flue gas as a potential source of nutrients during $\mathrm{CO}_{2}$ mitigation by microalgae. Algal Res 2016;17:285-92. https://doi.org/ 10.1016/j.algal.2016.05.017.

[40] Shang H, Scott JA, Shepherd SH, Ross GM. A dynamic thermal model for heating microalgae incubator ponds using off-gas. Chemical Engineering Science 2010;65:4591-7. https://doi.org/10.1016/j.ces.2010.04.042.

[41] National Energy Board. Canada's renewable power landscape 2017 - energy market analysis. 2017. Retrieved from, https://www.cer-rec.gc.ca/nrg/sttstc/lctrct/rprt/ 2017cndrnwblpwr/index-eng.html.

[42] Department of Planning, Industry, and Environment. NSW electricity strategy. 2019. Retrieved from: https://energy.nsw. gov.au/media/1921/download.

[43] U.S Agency for International Development (USAID). Zambia - power Africa fact sheet. 2020. Retrieved from, https://www. usaid.gov/powerafrica/zambia.

[44] U.S Energy Information Administration (EIA. Poland - independent statistics and analysis. 2020. Retrieved from, https://www.eia.gov/international/analysis/country/POL.

[45] Seyed Hosseini N, Shang H, Ross GM, Scott JA. Microalgae cultivation in a novel top-lit gas-lift open bioreactor. Bioresour Technol 2015;192:432-40. https://doi.org/10.1016/ j.biortech.2015.05.092.

[46] Laamanen CA, Shang H, Ross G, Scott JA. Smelter off-gas waste heat and carbon dioxide sequestration to promote production of biodiesel. Comer Ind Madera (CIM) J 2017;8: 1-12. https://doi.org/10.15834/cimj.2017.11.

[47] Seyed Hosseini N, Shang H, Scott JA. Optimization of microalgae-sourced lipids production for biodiesel in a top-lit gas-lift bioreactor using response surface methodology. Energy 2018; 146:47-58. https://doi.org/10.1016/j.energy.2017.08.085.

[48] Seyed Hosseini N, Shang H, Scott JA. Increasing microalgal lipid productivity for conversion into biodiesel by using a non-energy consuming light guide. Biochem Eng J 2018;134: 60-8. https://doi.org/10.1016/j.bej.2018.03.006.

[49] Chinnasamy S, Bhatnagar A, Hunt RW, Das KC. Microalgae cultivation in a wastewater dominated by carpet mill effluents for biofuel applications. Bioresour Technol 2010; 101:3097-105. https://doi.org/10.1016/j.biortech.2009.12.026.

[50] Acién Fernández FG, Fernández Sevilla JM, Molina Grima E. Photobioreactors for the production of microalgae. Rev Envriron Sci Biotechnol 2013;12:131-51. https://doi.org/ 10.1007/s11157-012-9307-6.

[51] Laamanen CA, Desjardins SM, Senhorinho GNA, Scott JA. Harvesting microalgae for health beneficial dietary supplements. Algal Res 2021;54:102189. https://doi.org/10.1016/ j.algal.2021.102189.

[52] Bilad MR, Vandamme D, Foubert I, Muylaert $K$, Vankelecom IFJ. Harvesting microalgal biomass using submerged microfiltration membranes. Bioresour Technol 2012. 111:343-52. https://doi.org/10.1016/j.biortech.2012.02.009.

[53] Dassey AJ, Theegala CS. Harvesting economics and strategies using centrifugation for cost effective separation of microalgae cells for biodiesel applications. Bioresour Technol 2013;128: 241-5. https://doi.org/10.1016/j.biortech.2012.10.061.

[54] Luo S, Griffith R, Li W, Peng P, Cheng Y, Chen P, et al. A continuous flocculants-free electrolytic flotation system for microalgae harvesting. Bioresour Technol 2017;239:439-49. https://doi.org/10.1016/j.biortech.2017.04.061.

[55] Sathish A, Sims RC. Biodiesel from mixed culture algae via a wet lipid extraction procedure. Bioresour Technol 2012;118: 643-7. https://doi.org/10.1016/j.biortech.2012.05.118.

[56] Chisti Y. Biodiesel from microalgae. Biotechnol Adv 2007;25: 294-306. https://doi.org/10.1016/j.biotechadv.2007.02.001.

[57] Demirbas A, Demirbas MF. Importance of algae oil as a source of biodiesel. Energy Convers Manage 2011;52:163-70. https://doi.org/10.1016/j.enconman.2010.06.055.

[58] Fukuda H, Kondo A, Noda H. Biodiesel fuel production by transesterification of oils. J Biosci Bioeng 2001;92:405-16.

[59] Sphera. GaBi solutions. 2021. Retrieved online: http://www. gabisoftware.com/canada/index/.

[60] ASHRAE handbook, 1985 fundamentals. Atlanta, Georgia: American Society of Heating, Refrigerating, and Air Conditioning Engineers, Inc.; 1985.

[61] Mousavi Maleki SA, Hizam H, Gomes C. Estimation of hourly, daily and monthly global solar radiation on inclined surfaces: models re-visited. Energies 2017;10:134. https:// doi.org/10.3390/en10010134.

[62] Desjardins SM, Laamanen CA, Basiliko N, Scott JA. Selection and re-acclimation of bioprospected acid-tolerant green microalgae suitable for growth at low $\mathrm{pH}$. Extremophiles 2021;25:129-41. https://doi.org/10.1007/s00792-021-01216-1.

[63] Cuaresma M, Garbayo I, Vega JM, Vílchez C. Growth and photosynthetic utilization of inorganic carbon of the microalga Chlamydomonas acidophila isolated from Tinto river. Papers from the 1st. Int Conf Environ Ind Appl Microbiol (BioMicroWorld-2005) 2006;40:158-62. https://doi.org/ 10.1016/j.enzmictec.2005.10.049.

[64] Moser M, Weisse T. Combined stress effect of $\mathrm{pH}$ and temperature narrows the niche width of flagellates in acid mining lakes. J Plankton Res 2011;33:1023-32. https:// doi.org/10.1093/plankt/fbr014.

[65] Souza ALB, Srur AO, Derner RB, Mendes MF. Technical feasibility of residual biomass of microalgae Desmodesmus sp. after supercritical extraction: evaluation of chemical composition. Revista Brasileira de Tecnologia Agroindustrial 2018;12:2578-91. https://doi.org/10.3895/rbta.v12n1.5189.

[66] Bernard O, Rémond B. Validation of a simple model accounting for light and temperature effect on microalgal growth. Bioresour Technol 2012;123:520-7. https://doi.org/ 10.1016/j.biortech.2012.07.022.

[67] Piiparinen J, Barth D, Eriksen NT, Teir S, Spilling K, Wiebe MG. Microalgal $\mathrm{CO}_{2}$ capture at extreme $\mathrm{pH}$ values. Algal Res 2018;321:8. https://doi.org/10.1016/j.algal.2018.04.021.

[68] Bharathan B, Sasmito AP, Ghoreishi-Madiseh SA. Analysis of energy consumption and carbon footprint from underground haulage with different power sources in typical Canadian mines. J Cleaner Prod 2017;166:21-31. https:// doi.org/10.1016/j.jclepro.2017.07.233. 
[69] Rajak U, Nashine P, Verma TN. Effect of Spirulina microalgae biodiesel enriched with diesel fuel on performance and emission characteristics of CI engine. Fuel 2020;268:117305. https://doi.org/10.1016/j.fuel.2020.117305.
[70] Anwar M, Rasul MG, Ashwath N. A pragmatic and critical analysis of engine emissions for biodiesel blended fuels. Fuel 2020;270:117513. https://doi.org/10.1016/ j.fuel.2020.117513. 